\title{
The Role of Mosque for Internalizing Pancasila through Ngaji Filsafat in MJS Yogyakarta
}

\author{
Ambiro Puji Asmaroini ${ }^{1}$, Ardhana Januar Mahardhani ${ }^{2}$, \\ \& Muhammad Afif Mahrus ${ }^{3}$ \\ ${ }^{123}$ Program Studi Pendidikan Pancasila dan Kewarganegaraan, \\ Universitas Muhammadiyah Ponorogo \\ 凶ambirop@gmail.com
}

Riwayat naskah: Diterima: 26 Agustus 2020

Disetujui: 15 Desember 2020

Diterbitkan: 21 Desember 2020

Abstract: The purpose of this research were, first, to describe the role of Jendral Sudirman Mosque (MJS), and second, to find out human value internalization in Pancasila through Ngaji Filsafat (Philosophy Discussion) at MJS. The research used a qualitative method with a descriptive type where the data collection was conducted through observation, interviews, and documentation. The informants were the administrator of MJS and participants of Ngaji Filsafat. The research showed that MJS has a vital role through its spiritual, intellectual, and socio-cultural functions. Furthermore, through the Ngaji Filsafat held in MJS, it is a place of worship and has potential in the realm of scholarship that could be utilized not only by academics and Muslims but also by the broader community of interreligious groups by promoting humanitarian awareness. Internalization of Pancasila's human values explicitly also existed through Ngaji Filsafat, such as respecting opinions, caring for others, and respecting other people's rights and obligations.

Keywords: internalization; human value; masjid jendral sudirman; ngaji filsafat; philosophy; role of mosque

Abstrak: Tujuan penelitian ini adalah, pertama, mendeskripsikan peran Masjid Jendral Sudirman (MJS), dan kedua, mengetahui internalisasi nilai kemanusiaan dalam Pancasila melalui Ngaji Filsafat di MJS. Penelitian ini menggunakan metode kualitatif dengan tipe deskriptif. Pengumpulan data dilakukan melalui observasi, wawancara, dan dokumentasi. Informannya adalah Takmir MJS dan peserta Ngaji Filsafat. Hasil penelitian menunjukkan bahwa, pertama, masjid berperan untuk kemakmuran melalui tiga fungsi, yaitu spiritual, intelektual, dan sosial budaya. Kedua, melalui Ngaji Filsafat yang dilaksanakan di masjid, tidak hanya sebagai tempat ibadah tetapi juga memiliki potensi di bidang keilmuan yang dapat dimanfaatkan tidak hanya dari kalangan akademisi dan umat Islam tetapi oleh masyarakat luas dan semua golongan serta antar agama dengan mempromosikan nilai humanitarianisme. Internalisasi nilai-nilai kemanusiaan dalam Pancasila secara eksplisit juga ada melalui Ngaji Filsafat seperti menghargai pendapat, peduli kepada sesama, dan menghormati hak dan kewajiban orang lain.

Kata kunci: filsafat; internalisasi; masjid jendral sudirman; ngaji filsafat; nilai kemanusiaan; peran masjid 


\section{Introduction}

In Rasulullah's era, the mosque became an essential place in playing the role of a social movement. The mosque was not only a place to do religious rites (mahdhah worship) as well as social ones (ghairu mahdhah). In the history of the emergence of the mosque's function, it did not stop at the literal meaning of being a worship place, but to be multifunctional. During the early Muslim generation era, it also became a place for knowledge-purposed activities ranging from the formation of the people's character to the center of economic, political, social, and cultural activities. Hence, the mosque is a place to educate, shape, cultivate and develop the thinking of the world and the Islamic world. ${ }^{1}$

The first education process recorded in the history of Islamic civilization was at a mosque in Madinah city in 653 AD. In Damascus, the mosque school first appeared in 744 AD. Furthermore, consecutively, almost every mosque also functioned for education purposes and had primary schools spread throughout the world in the $9^{\text {th }}$ Century. ${ }^{2}$

In Indonesia's history, the mosque also played an important role. It was not only serving as a worship place as its primary function, but also as a place to, for instance, gather in the Bahtsul Masa'il (discussing problems). In this place, people might hold a deliberation to make decisions and a place of education that could accept all classes without class discrimination or social stratification. $^{3}$

However, in the Dutch colonial era, its function was limited. Mosque was only allowed to be used as a worship place. The situation was caused by the suspicion that the mosque could be used as a base to build a mass power against the colonial government. The Dutch made restrictions for the colonies to gather and consult in order to resist the colonizers. The mosque could indeed be an effective place to develop an anti-colonial movement. Under the pretext of jihad fi sabilillah, the spirit of fighting against the colonizers would be very effectively built in the mosque. As a holy place, the mosque would be able to be used to raise the spirit of resistance. Therefore, the Dutch government limited the mosque as merely a place to gather and discuss worship issues. ${ }^{4}$ Having a function as a worship place; thus, the mosque is then only a place of mahdhah worship.

Nevertheless, during the course when the mosque function in Indonesia should be kept into its basic necessity, mosques remained a place where Muslims can gather and share ideas and have dialogues about science and humanity problems. The proof of how essential and its influence to Indonesian civilization was acculturation from the aesthetic point of building construction, the layout position of the mosque building within the wider public surrounding, including the government building (pendapa) and the socio-economic center (alun-alun). Take Jami' Mosque in Malang, for example, which has constructed buildings combining several typologies of facades and transforming them into a new formation. The development is done by displaying a domed

\footnotetext{
${ }^{1}$ Sidi Gazalba, Masjid Pusat Ibadah Dan Kebudayaan Islam (Jakarta: Pustaka Antara, 1971).

2 Saddam Husein, "Peran Masjid Dalam Pendidikan Islam Nonformal Untuk Pembinaan Umat (Studi Kasus Di Masjid Mardhatillah Gempol Ngadirejo Kartasura Sukoharjo)" (Universitas Muhammadiyah Surakarta, 2015).

3 Faizal Amin and Rifki Abror Ananda, "Kedatangan Dan Penyebaran Islam Di Asia Tenggara: Telaah Teoritik Tentang Proses Islamisasi Nusantara,” Analisis: Jurnal Studi Keislaman, 2019, https://doi.org/10.24042/ajsk.v18i2.3069.

${ }^{4}$ Ahmad Sutarmadi, Manajemen Masjid Kontemporer (Jakarta: Balai Penerbit Fakultas Syariah dan Hukum UIN Syariah Hidayatullah, 2010).
} 
roof and minaret as the mosque's universal characteristics while maintaining a traditional tajug roof and the use of wood material as a characteristic of locality. ${ }^{5}$ The mosque function there were many activities carried out within the framework of developing Islamic culture.

Mosques in Indonesia have a very distinctive style. Furthermore, the mosque is known for the style of typical Javanese, Sumatra, Sulawesi and so on. For example, a typical Javanese mosque can be seen in the Demak Mosque with its Javanese style of building; ${ }^{6}$ also in Ponorogo, East Java, the Tegalsari Mosque. There was a typical Javanese mosque architecture also used as a pesantren boarding school to this day. The Tegalsari Mosque area is also listed in the National cultural heritage, so it is obligatory to preserve both the building and the cultural heritage. ${ }^{7}$

Suppose the most important education is the environment, and the mosque is one of the instruments in carrying out daily activities. In that case, the potential contained therein must become a serious discussion, considering that Muslims always gather to carry out at least once a week. The mosque's reduced role, especially in the scientific field, widely causes a demarcation between the mosque and science, between the mosque and the history of the nation's struggle, between the mosque and cultural values, the norms of customs that are crystallized in the Pancasila, Indonesia's basis of the state. Considering that mosque for humans, especially Muslims, was the most strategic place to discuss society's problems when Ki Hajar Dewantara resisted Onderwijs Ordonantie. It came out that every place could be as school and everyone was a teacher, weren't they?. ${ }^{8}$

As the nation that upholds Pancasila, it is a must for Indonesian people to practice their values. The main problem in its practice is how the general and universal abstract values can be described in the form of explicit norms relating to the behavior in society, nation, and state and aspects of state administration. ${ }^{9}$ In this case, an instrument needs to internalize the values in Pancasila. Pancasila is the basis of the Indonesian state's philosophy, whose values have existed in the Indonesian nation since time immemorial, in the form of customs, culture, and religious values. Thus the principle of Ketuhanan Yang Maha Esa has its value in the Indonesian nation as a materialist cause. ${ }^{10}$

It is not only in formal education but also in alternative forums. ${ }^{11}$ As explained above, the role of the mosque is significant. Thus, the potential to make the mosque as an alternative movement instrument in internalizing noble values as well as the humanity contained in Pancasila

5 Qurrotul A'yun, “Transformasi Bentuk Fisik Pada Tipologi Fasade Masjid Jami' Malang," EMARA: Indonesian Journal of Architecture, 2016, https://doi.org/10.29080/eija.v1i2.9.

${ }^{6}$ Abdul B. Zein, Masjid-Masjid Bersejarah Di Indonesia (Jakarta: Gema Insani Press, 1999).

7 Dawam Multazamy Rohmatulloh, "Local Muslim Heritage: Pelestarian Warisan Budaya Pesantren Di Tegalsari Ponorogo," Proceedings of Annual Conference for Muslim Scholars, 2018. http://proceedings.kopertais4.or.id/index.php/ancoms/article/view/125

${ }^{8}$ Ahmad Tanaka, "SISTEM AMONG, DALTON, DAN SHANTI NIKETAN Kajian Komparatif Historikal Sistem Pendidikan Indonesia, Amerika, Dan India Serta Implikasinya Bagi Kemajuan Pendidikan Di Indonesia Konteks Kekinian,” Jurnal Teknologi Pendidikan Madrasah, 2018.

9 Yoga Putra Semadi, "Filsafat Pancasila dalam Pendidikan di Indonesia Menuju Bangsa BerkarakteR," Jurnal Filsafat Indonesia, 2019, https://doi.org/10.23887/jfi.v2i2.21286.

10 Nurhadianto Nurhadianto, "Internalisasi Nilai-Nilai Pancasila dalam Upaya Membentuk Pelajar Anti Narkoba,” JURNAL PENDIDIKAN ILMU SOSIAL, 2016, https://doi.org/10.17509/jpis.v23i2.1618.

${ }^{11}$ Ardhana Januar Mahardhani, "Pemberdayaan Masyarakat Melalui Pendidikan Nonformal Berkarakter Cinta Tanah Air,” Jurnal Pancasila Dan Kewarganegaraan, 2018, https://doi.org/10.24269/jpk.v3.n2.2018.pp56-63. 
is an opportunity. Considering that humanity is a significant aspect of life as a human being and humanizing humanity.

Discourse and themes revealed in mosques are not only about Islamic practical teachings but also the development in social, cultural, economic, and humanitarian issues, even critical thinking or discourse. Because in a mosque and its environment, there is not only one old group but also the young group, which will be a connector of leadership relay. Adjustments to social culture are also needed to build interest and awareness of spiritual needs. ${ }^{12}$ One of the profound examples of such case as practiced in Jendral Sudirman Mosque will be discussed in this paper.

Jendral Sudirman Mosque in Kolombo Yogyakarta (abbreviated from now on as MJS Masjid Jendral Sudirman) was built in 1394 H/1974 AD. It was initially a small mosque/mushala used for regular religious activities such as congregation prayer. The mushala was a branch of the Syuhada Mosque located on Jl. I Dewa Nyoman Oka, Kotabaru, Gondokusuman, Yogyakarta. The establishment of the MJS was initially initiated by several people who were active in the activities at Syuhada Mosque, and some were members of the takmir of the Syuhada Mosque. MJS has the core of the movement to prosper the mosque towards a series of spiritual frame activities, honing intellectualism while observing culture (spiritual, intellectual, and sociocultural). All three emphasized that the mosque is a place of worshipping and study.

Furthermore, in the role and function in education, MJS has Al-Quran education School for children (TPA) Sudirman and study groups based entirely on the three foundations of the mosque's movements: spiritual, intellectual and social-cultural. Implementation of the three through each activity is held routinely at MJS. The routine activities at MJS include (1) Ngaji Filsafat (Philosophy Discussion), which was held at the first time in April 2013. It is now routinely held every Wednesday night after Isha' prayer, discussing the themes on Greek, Western, Eastern, Islamic, and Archipelago philosophies through classical, modern, and postmodern perspectives; (2) Ngaji Hikam (Hikam Discussion), that is studying the Al-Hikam book by clerics Shaykh Ibn Atha'llah, which is held every Monday Wage night after Isha' prayer; (3) Madrasah Diniyah (Madin) that is held every Tuesday and Friday. It begins after Maghrib prayer until before Isha' prayer. The Madin learns the interpretation of the Qur'an, Fiqh, and question and answer about worship and Islam, Sirah Nabawiyah, and many others; (4) Ngaji Serat Jawa, a study discussing the teachings of Sunan Prawata, Panji Jayabaya, Topah Book, and others; (5) Ngaji Rubaiyat, studies the work of Jalaluddin Rumi, which contains more than a thousand verses of poetry performed every selapanan (once in a month); (6) Ngaji Tarjuman alAswaq, a book by Ibn Arabi also every selapanan; (7) Ngaji Qur'an; (8) Ngaji Pascakolonial; and (9) Mosque Literacy, where MJS has a library and book publishing. MJS Literacy is a community established on 29-30 April 2016 which was engaged in joint writing projects from the Ngaji's MJS ever conducted. Furthermore, in the field of publishing, the mosque has MJS Press which was established in May 2016.

Based on the explanation above, this research's study purposes are; first, how MJS played a role in implementing scholarship development, and, second, how humanitarian Pancasila values can be internalized through the Ngaji Filsafat of MJS.

12 Ardhana Januar Mahardhani \& Hadi Cahyono, "Harmoni Masyarakat Tradisi Dalam Kerangka Multikuluralisme,” ASKETIK, 2017, https://doi.org/10.30762/ask.v1i1.408. 


\section{Method}

This research uses a qualitative method with a descriptive approach. ${ }^{13}$ Located at the Jendral Sudirman Mosque (MJS) Yogyakarta, this research was conducted from January to March 2020. The researchers collected data through observation, interviews, and documentation. The key informants in this study are Wahid and Rahman, both are the MJS administrators (takmir) while the latter is also performing as a participant of Ngaji Filsafat. Researchers carried out observations by following activities at MJS, while interviews were conducted openly to study participants, administrators, and presenters who were present in the Ngaji Filsafat discussion forum, and documentation was collected from archives of activities that had been carried out; books used in the study; as well as other sources in the form of articles and books in accordance with the theme of this paper. The data analysis technique used three stages of the Miles and Huberman model: data reduction, data presentation, and conclusion drawing or verification. ${ }^{14}$

\section{Scholarly Development in MJS}

The role and function of MJS are the same as other mosques in general in the area of religious ritual practices. However, the engagement and exploration of the potential roles and functions of the MJS mosque are the exceptions. Only few administrators think about social and religious activities that sustain intellectuals. MJS has several agendas including a philosophy study that is routinely carried out on Wednesday nights. To attract people to engage with the mosque, the main base of MJS is spirituality, intellectuality, and socio-culture. Wahid argued, "Ketiga hal yang menjadi pedoman dari masjid, yaitu sebagai landasan spiritual dan intelektual. Dapat kita lihat bahwa kemarin kita mengadakan rapat besar MJS untuk membahas berbagai kegiatan. Selanjutnya adalah aspek sosial budaya, dalam istilahnya hal ini adalah inti dari spiritual dan belajar tentang intelektual dengan cara nguri-nguri budaya" (The three things are the guideline of the mosque. As the initial basis is spiritual and intellectual. We can see that yesterday we conducted the MJS big meeting, so the third is social-cultural aspect. The language term is the core of spiritual, but learning intellectual is also with nguri-nguri budaya). ${ }^{15}$

The basis becomes the direction or guideline of MJS to conduct agendas. MJS has a focus on reviving and caring for culture through mosques. It includes reviving the scientific culture that is centralized in the mosque. Making the mosque a spiritual, intellectual, and social-cultural center is an attraction of MJS.

In this modern era, the role and function of the mosque are reduced. Mosque is merely a place for conducting the five daily prayers and other mahdhah worship. Many potentials are not able to be realized. Considering that the mosque is a gathering place for Muslims at least once a week, every Friday when the Friday prayer is held. Creativity and experimentation from the management are needed in this regard. Wahid said, "Ya, dilihat juga budaya, dan di mana masjid itu berdiri, bagaimana peran pengurusnya. Mungkin para pengurus dapat mengadakan kegiatan yang memungkinkan dilakukan di masjid" (Yes, it is also seen what the culture is, where the

\footnotetext{
${ }^{13}$ Suharsimi Arikunto, Metodologi Penelitian, Bumi Aksara, 2013.

${ }^{14}$ Lexy J. Moleong, "Metodologi Penelitian Kualitatif (Edisi Revisi)," PT. Remaja Rosda Karya, 2019, https://doi.org/10.1016/j.carbpol.2013.02.055.

${ }^{15}$ Wahid, Takmir Masjid Jenderal Sudirman, personal interview, January 9, 2020.
} 
mosque stands, and the main role of the management. Maybe they can hold the activities that make it possible to do by the mosque). ${ }^{16}$

The downgrading of mosques' role and function made takmir of MJS conducted activities to re-promote the mosque as an exciting place. One of the administrators of the MJS, Rahman, also explained that it needs social capital to prosper the mosque. Because MJS has social capital in urban areas and the number of universities and students, the optimization of the mosque's role and function can be carried out with all existing MJS agendas. Rahman added, "Lihat situasinya apa, maunya apa, kalau di Jogja adanya keraton dan Jawa ya basis kebudayaan, kemudian Jogja, pendidikan ya basisnya pendidikan, terus dari sisi agama ya spiritual, adanya masjid apalagi, ya itu basisnya. (Let us see the situation and what the people want. Yogyakarta has palaces as Javanese culture base, and universities as the basis of education, then the side of religion is spiritual so that we can approach people from the mosque)". ${ }^{17}$

\section{MJS main typical activities}

Spirituality. MJS has the primary function as a place of worship similar to other mosques in general. Wahid stated, "Semua gerakan kita mengarah ke masjid, sujud adalah rasa penyerahan diri. Dalam pengertian luas, semua yang terbentang di muka bumi ini adalah masjid, maka biasakan sujud di manapun kita berada agar bisa menjadi manusia yang berserah diri (All our moves leads to the mosque, prostration is the sense of submission. In a broad category, all that unfolds on this earth is a mosque, then get used to prostrating is wherever we are in order to be submissive as servants)"18. In basic of spirituality, MJS runs some activities such as theological studies. Every activity and a series of agendas carried out are always in a spiritual frame. In actualizing, takmir of MJS are destined to be a servant. Those routine agendas to instill the spirituality are by studying Sufistic classic books such as Jalaluddin Rumi's Rubayyat, Al-Hikam by Ibn Athaillah, and Tarjuman alAswaq by Ibn Arabi. Besides, it also held studies of Fiqh and so on.

Intellectuality. MJS is located in a province with the predicate city of students, Yogyakarta. It must be a benchmark to put the main basis of how and where the mosque is going. It has been explained above that one of the core movements of the MJS is Intellectual. In its history, MJS has become the mosque that has the best mosque-based TPA. Then MJS also becomes a strong magnet for seekers of knowledge and students as well. It could be seen from every activity carried out at MJS that is always crowded with children, youth, to the elderly. At first, in the implementation, MJS often conducted discussion forum that focused on philosophy in classes, as Nur Wahid explained. As long as the time goes by and there are interests of many santri, the activity is then conducted at the mosque.

Furthermore, the Mosque Literacy Program is also held. It is actually scarce for mosques to carry out these activities. By utilizing the existing potential and the enthusiasm of young people as students in various universities in Jogja, takmir of mosque seeks to realize mosque literacy. Many activities that are held at MJS are close to the scholarship milieu in

\footnotetext{
${ }^{16}$ Wahid, Takmir Masjid Jenderal Sudirman, personal interview, January 9, 2020.

${ }^{17}$ Rahman, Ngaji Filsafat Participant and Takmir Masjid Jenderal Sudirman, personal interview, January 9 ,

${ }^{18}$ Wahid, Takmir Masjid Jenderal Sudirman, personal interview, January 9, 2020.
} 2020. 
building intellectual, reviving scientific forums in mosques such as Ngaji Filsafat (Philosophy Discussion). Those activities are hence the source of intellectual aspect of MJS. Geographically, MJS stands between large campuses, public campuses, private campuses, and Yogyakarta-based campuses with an atmosphere of education closely linked to the discussion culture. Such culture makes social capital to intensify activities at MJS. It facilitates the spirituality side and intellectual needs, where young people are the basis of millennials keen on a scientific approach. Thus, MJS becomes a unique attraction for young people.

Culture. The MJS has some unique history. As a so-called radical group ever once controlled MJS, so there was a perception that the mosque was affiliated with Islamist networks. It made people keeping a distance from this mosque so that the activities had to be stopped. It proves that the reduction of the role and function of MJS was exist. In responding to that situation, there was an effort by MJS Takmir to re-shape the image of MJS as a mosque central to civilization, by taking a tag line of nguri-nguri budaya. Cultural activities began to be lively again when MJS held an exciting event. The tight relationship of Keraton and the Javanese culture and the idea which brings MJS towards a new direction does not mean that a mosque is affiliated with a particular ideology. The agendas are sinau tembang macapat (learning Javanese Poetry), learning Wayang (Puppet), Javanese Song, Javanese serat suluk (literature). Those agendas are routine activities at MJS in developing a Javanese cultural framework. Thus, one said that the mosque was increasingly crowded and frequented by the ancestors. ${ }^{19}$

The implementation of social-culture in MJS more often uses the discussion forum method. Based on Wahid's opinion, in every MJS forum activity while giving food to the congregation, it always uses Javanese culture. There are no bottled drinks, and it always uses glass as when the dayoh pladen (waitress).

Wahid argued, "Ketika waktu Maghrib dan Subuh tiba kami memutar kaset (murattal), kemudian muadzin juga sering menggunakan gaya Jawa dalam adzannya. Tentunya kita harus memahami bahwa Islam dan Jawa tidak dapat dipisahkan. Pemisahan itu karena konstruksi jaman kolonial yang cukup intens dengan gerakan-gerakan yang menginginkan gerakan pemurnian Islam. Islam masuk ke sini melalui jalur budaya” (When the Maghrib and Fajr come, we play tapes reciting al-Qur'an, and then the muadzin often uses Javanese style and adzan/call to prayer as well. We should understand that Islam and Javanese are not separated. The separation is due to colonial construction. Islamic and Javanese have the same thing. Maybe this is quite resistant to movements that want the purification of Islam. Islam entered here because of the cultural route). ${ }^{20}$

From his explanation, it can be known that the mosque and culture's role and function are not separated. It can be seen that the construction of the classic mosque building is identical to the culture around it. The mosques in Java will be akin to the form of pyramid and roof arrangements. Mosques in Chinese villages will have a form that tends to be nuanced with Chinese culture. Therefore, directing the mosque to culture means neutralizing extremist

${ }^{19}$ Fejrian Yazdajird Iwanebel, "Gerakan Keagamaan Dan Identitas Kultural Masjid Jendral Sudirman Yogyakarta," IBDA: Jurnal Kajian Islam Dan Budaya 17, no. 1 (2019).

${ }^{20}$ Wahid, Takmir Masjid Jenderal Sudirman, personal interview, January 9, 2020. 
and radical movements. Because the Islamist movement often clashes with local cultural traditions with Arabic culture, which is considered a sacred culture that is hereditary from the prophetic tradition.

\section{Role Played by MJS}

From the mentioned activities of MJS, we can see that MJS has succeeded in developing the understanding that the mosque is used as worship and for the development of knowledge. In the discussion, several things will be elaborated regarding the role and function of the MJS. First is as a means of worship and the development of spirituality. The second is as a means of education or intellectual, and the third is as a social and cultural society.

\section{Worship and spirituality}

As the mosque built in urban and heterogeneous people, MJS has many roles and functions besides the mosque's main function as a place to perform rituals of worship for Muslims. With the motto "mari, menuju masjid membudayakan sujud", the MJS puts the foundation of its movement on the principle of spirituality. Prostration (sujud) in this notion means obedience. In framing this activity with spiritual values, MJS conducts a Sufi study. A Sufi is someone who views religion in terms of love. A path is taken in the direction of something that is true, that is prevailing the authenticity of life and the authenticity of who is a being (makhluq) and who is the creator (khaliq). Basically, the preferred service in the mosque is to establish prayer. Prayer has the meaning of "connecting" that is the connection between the makhluq and the khaliq. Therefore, prayer does not only mean worship.

\section{Education and intellectual}

In this regard, as MJS located in Education City Yogyakarta, MJS also plays role as a facilitator in the field of education. In this domain of education, MJS forms educational institutions for children. MJS Al-Qur'an Education (TPA) was established in 1990. Furthermore, to complete the field of education with objects of children, in 2013, scholarship study forum was formed with an academic such as the Ngaji Filsafat. Then other studies with various themes began to be encouraged. The existence of mosque in the middle of community absolutely has the important role in daily life. Basically, the mosque is from the people and for the people. MJS organizes the agenda of Tahsin Qur'an training activities for women who need. Thus, the benefits can be felt directly by the community. Education becomes a major milestone in the progress of the quality of human life. Paulus Kristianto suggested that education according to the platoon is based on the view of humans. If the core of a human being is their soul, then education for humans must have a clear vision and mission about the soul and how we can touch, develop, and orient students' souls so that we lead to our direction. ${ }^{21}$ In another meaning, educating is a major focus in building the human soul. If the essential of human beings is the soul, educating the soul is the center of identity to open the treasury of knowledge and recognize themselves and their environment to their God. Basically, mosque as the center of education has been existed

${ }^{21}$ Paulus Eko Kristianto, "Resensi: Paideia Filsafat Pendidikan-Politik Platon," GEMA TEOLOGIKA, 2017, https://doi.org/10.21460/gema.2017.22.355. 
since Rasulullah era. Rasulullah in delivering his guidance to the Muhajirin and Ansar said that the role and function exists because of the potential contained in the mosque such as the ease of people gathering while performing the obligatory prayers and others. Thus, the authors can see how necessary it is to facilitate the whole community and understand the characteristics of the mosque's environment. Therefore, the potential exists and the mosque can be re-crowded with alternative scientific forums other than other formal places such as campuses and schools. Because non-formal alternative discussion forums are usually more intense because it departs from feeling rather than feeling burdened.

\section{Socio-cultural affair}

MJS has a characteristic that is close to the culture. This is based on the geographical location in Yogyakarta's city with identical to the palace and Javanese culture. Then with the "nguri-uri budaya" jargon, MJS becomes one of the mosques that hold fast to local wisdom or a mosque that do not eliminate local wisdom that had been passed down through generations. Through the cultural activities such as sinau tembang macapat (studying Javanese Poetry), sinau wayang (puppet), Javanese song and literature (serat suluk) and philosophy, MJS develops the framework of Javanese culture. Thus, there was a congregation who said that the mosque was increasingly crowded and frequented by ancestors. ${ }^{22}$ Basically, mosque and culture in the environment of the mosque cannot be separated. The separation between the mosque and local wisdom, according to Wahid, is a colonial construction. The unity formed can be seen from the architecture and models of existing buildings, such as the Yogyakarta Great Mosque, the Great Mosque of Demak and others.

Table 1. Scholarship development in the activities in MJS

\begin{tabular}{|c|l|}
\hline $\begin{array}{c}\text { Core of the MJS } \\
\text { motion }\end{array}$ & \multicolumn{1}{c|}{ Explanation of the role of MJS } \\
\hline Spirituality & $\begin{array}{l}\text { As the mosque built in urban and heterogeneous people, } \\
\text { MJS has many roles and functions besides the main function } \\
\text { of the mosque as a place to perform rituals of worship for } \\
\text { Muslims }\end{array}$ \\
\hline Intellectual & $\begin{array}{l}\text { In education aspect, MJS also plays role as a facilitator in the } \\
\text { field of education. The potential exists and the mosque can } \\
\text { be re-crowded with alternative scientific forums that is non- } \\
\text { formal alternative discussion forums }\end{array}$ \\
\hline Culture & $\begin{array}{l}\text { This is based in Yogyakarta with identical to the palace and } \\
\text { Javanese culture. Then with the jargon is "nguri-uri", MJS } \\
\text { becomes one of the mosques that hold fast to local wisdom } \\
\text { or a mosque that do not eliminate local wisdom that had } \\
\text { been passed down through generations. }\end{array}$ \\
\hline
\end{tabular}

In fact, mosque is from people and for people. Thus, the mosque's role and function as a social medium as on Table 1 depict a form of mosque engagement with society. The role of mosques in society is very important, especially to provide solutions to public problems. The implementation of programs and agendas are designed to answer solutions from social problems.

${ }^{22}$ Iwanebel, “Gerakan Keagamaan Dan Identitas Kultural Masjid Jendral Sudirman Yogyakarta.” 
The mosque has a vital position in providing solutions to social problems if it is truly run according to its function. ${ }^{23}$

The authors argue that by the awareness that the mosque's reason is built from all aspects, including local wisdom, it will make the community also open and aware that the mosque is a common property, not belonging to any group or sect. Thus, the mosque is truly able to optimize all existing potentials as well as social society. This indicates Islam's intimacy with the culture where it is located; wherever the Islamic teachings encounter any cultural values at a local place, the entanglement occurs. ${ }^{24}$ Acculturation that performs consecutively shows that in every aspect, Islam can be absorbed into every line of people's lives. Communities that are built in tandem with the existing culture are not separate from something transcendent that has become a spiritual practice. thus, many Javanese people became Muslim, for instance.

\section{Internalization of Human Value in Pancasila through Ngaji Filsafat Forum}

The term of "Ngaji Filsafat" (Philosophy Discussion) was originated only from a small talk. It came from Javanese habits in saying the word "ngaji" in the stead of "Kuliah Filsafat (Lecture on Philosophy)", which the latter seemingly made it too formal and became a burden for wider audiences. However, the caretaker of MJS, Fahruddin Faiz, has a hermeneutical reason behind the choice of the word "Ngaji". He took from the word aji which means 'ke-mulia-an' (glory). Ngaji means an attempt to become noble or seek glory. In Islam, aji is parallel to the word karamah. Thus, according to him, "Ngaji Filsafat" means efforts to seek glory and becomes noble with philosophy. ${ }^{25}$

Ngaji Filsafat at MJS was first held on Sunday, 21 April 2013. It was agreed later that the regular Ngaji Filsafat would be held every Wednesday at 20:00 to 22:00. Many themes studied in Ngaji Filsafat include Greek philosophy, Western philosophy, Eastern philosophy, and Islamic philosophy to the philosophy of Java. Then, the study of the philosophy began from classical philosophy, modern philosophy and postmodern. In addition, it also discusses about figures of Greek, West, East, Islam and Javanese philosophy.

Studying philosophy at MJS is the most favorite study. Media affects toward the publication of each philosophical study with existing themes. Besides the role of the media, the role of speakers who come from academics, of course, has the expertise in conveying every philosophical material into simple language and by analogy that is easy to digest. One of the early students who is now helping MJS takmir, Rahman, said: "Pembicaranya sangat kompeten, termasuk dari kalangan akademisi, kampus-kampus agama yang ada di Yogyakarta. Oleh karena itu saat menjelaskan materinya sangat gambling dalam menyampaikannya. Mudah untuk

${ }^{23}$ Teuku Supardi Amirudin, Manajemen Masjid Dalam Pembangunan Masyarakat (Yogyakarta: UII Press, 2001).

${ }^{24}$ Arik Dwijayanto \& Dawam Multazamy Rohmatulloh. "Ponorogo, the Little Java: Potret Kebudayaan Dan Keberagamaan Masyarakat Muslim Ponorogo Abad XX". Al-Adabiya: Jurnal Kebudayaan Dan Keagamaan 13, No. 01 (2018). https://doi.org/10.37680/adabiya.v13i01.2

${ }^{25}$ Fahruddin Faiz, Transkrip Ngaji Filsafat: Butir-Butir Kebijaksanaan Sufi Nusantara (Yogyakarta: Omah Ilmu, 2020). 
dipahami" (The speakers are very competent, including from academics of religious campuses in Yogyakarta. Therefore, when he explains the material, it is easy to understand). ${ }^{26}$

From the argument above, we can see that speakers' role has a significant effect, especially in understanding philosophy and philosophical thinking. Philosophy is still something strange in some places, even though philosophy is the 'mother' of scientific disciplines. The need for philosophical study framework of thought in determining humane attitudes, actions and lives is necessary.

Therefore, it is to make human to be able to think critically toward issues and consider what they will decide. In his book Thinking Skill, Faiz explained what critical thinking is. He argues that critical thinking is a mental activity in an effort to investigate a statement that in the end a statement is true or accepted, false or rejected or still doubtful because they have not received an answer. $^{27}$

The widespread information on philosophy studies conducted by MJS through the media has an effect in changing the stigma that philosophy is difficult and confusing. Yet, there are still many people who are unfamiliar with philosophy and think that philosophy is difficult and some even forbid it. In this case, Wahid exemplified, "Hal itu tergantung pada anggapan bahwa filsafat sebagai alat atau sebagai produk karena jika itu adalah produk pemikiran, itu menghasilkan sebagai pernyataan Nietzche bahwa Tuhan sudah mati, itu produk berpikir. Tetapi jika itu sebagai alat, maka muncul pertanyaan, mengapa Nietzche berpikir seperti itu" (It depends on considering philosophy as a tool or as a product because if it is a product of thinking, it generates as Nietzche's statement that God is dead, that's the product of thinking. But if it is as a tool, then the question arises, why does Nietzche think so). ${ }^{28}$

From the argument above, we need to understand that philosophy is the way how humans think. If the mind is a tool how humans use these tools in producing a product. It is very clear how a tool produces a product rotating relationship that does not stop as long as the device is still functioning and the product is still sold. As a subject who can know whether a product is good or failed, a subject who can use his mind (tool) well and know how the product can be good or fail.

Furthermore, in the implementation of human value in Pancasila is such as respecting opinions, caring for others, respecting the rights and obligations of others. This is true in both the forum and forum material, although there is not directly such an example as the big theme of Pancasila. The elements in Pancasila already exist in our society such as customs which are rich in cultural and traditional values, living together in mutual cooperation, a sense of brotherhood and close kinship since long time ago, so that most Indonesian people both in the past and the present no longer look at what a person's background. ${ }^{29}$

However, these values are implicitly found in each theme of the forum study. Changes in the quality of thinking and attitude in each individual is also manifested. Rahman stated, "Setiap orang mempunyai perubahannya sendiri, saya juga punya perubahan, lebih bijak jika ada

${ }^{26}$ Rahman, Ngaji Filsafat Participant and Takmir Masjid Jenderal Sudirman, personal interview, January 12, 2020 .

${ }^{27}$ Fahruddin Faiz, Thinking Skill: Pengantar Berpikir Kritis. (Yogyakarta: Suka Press, 2012).

${ }^{28}$ Wahid, Takmir Masjid Jenderal Sudirman, personal interview, January 9, 2020.

29 Muhammad Mona Adha and Erwin Susanto, "Kekuatan Nilai-Nilai Pancasila Dalam Membangun Kepribadian Masyarakat Indonesia," Al-Adabiya: Jurnal Kebudayaan Dan Keagamaan 15, no. 01 (July 4, 2020): 121-38, https://doi.org/10.37680/adabiya.v15i01.319. 
masalah dipikirkan dahulu, tidak langsung emosional dan jangan reaksioner. Jika ada berita harus dicek dahulu. Ini adalah kritis dalam diri dan untuk diri sendiri" (Everyone has their own changes, I also have changes. Yes, it is wiser when there is a problem, just think first, not directly emotional first, not reactionary. When there is news, it must be checked. Critical is in the form of self, for self). ${ }^{30}$ What was conveyed by Rahman apparently also not only happened to his personal self, but also he got a story from the experience of his friends, Rahman also said, "Bahkan ada yang mengundurkan diri dari pekerjaannya untuk memahami filosofi ini, aktivitas Ngaji Filsafat sudah membuat saya memikirkan kembali pekerjaan yang saya lakukan sekarang” (Some even will resign from their work to better understand this philosophy, the Ngaji Filsafat activity makes me rethink in the work that I do now).

From the explanation of Rahman and his experience at MJS, it seems that the resonance of Ngaji Filsafat does not only for academics who do understand that scientific issues. Changes from each individual in thinking, behaving and socializing occur. As an alternative scientific means, Ngaji Filsafat is like an oasis or fresh air. Every individual can access through the media or attend the study. Wahid argued, "Ngaji Filsafat terbuka untuk umum dan semua kalangan, ada juga non muslim yang bergabung, seperti mahasiswa dari kampus non muslim, ada juga yang dari Malaysia. Tidak ada masalah sama sekali, seperti yang disampaikan pemateri pada saat ngaji, semua tergantung dari niat" (Ngaji Filsafat is open to the public and all circles, there are also non-Muslims who take part, such as students from non-Muslim-based campuses, some people are also from Malaysia. There is no problem at all, as said by the speaker during Ngaji, all depends on the intention). ${ }^{31}$

That explanation proves that the community of Ngaji Filsafat is very aware of the Indonesian nation's plurality, respecting for humanity, awareness of respecting the rights and obligations of every human being embedded. With good intentions, it will surely realize a good product. It is in accordance to one hadith of Rasulullah, "Everything depends on the intention". The practice can't be separated from how a mosque with its culture and social attitude is formed through teaching, practicing and civilizing. In the implementation, Ngaji Filsafat does not have any formal aim such as blue print or any principles. As Ngaji Filsafat is one of a series of events at MJS, it refers to the three things: spiritual, intellectual and socio-cultural.

Philosophy in some places has still been a strange thing. In fact, philosophy is 'the mother' of scientific disciplines that exist today. The need for philosophical study as a framework of thought in determining humane attitudes, actions and lives is necessary. Considering how reactionary the media community or netizens are now, and how easy it is to receive information, without looking for that information validation. Until there is debate in the column of social media comments, as well as the ignition of conflicts deliberately campaigned by irresponsible people. Next, we need a way that is capable of internalizing humanity awareness.

Philosophy basically can be defined as loving wisdom, noble knowledge or an inquiry into the nature of things. Ibn Rushd said that philosophy is wisdom, an autonomous knowledge that

${ }^{30}$ Rahman, Ngaji Filsafat Participant and Takmir Masjid Jenderal Sudirman, personal interview, January 12, 2020.

${ }^{31}$ Wahid, Takmir Masjid Jenderal Sudirman, personal interview, January 10, 2020. 
humans need to have because God is endowed with reason. Philosophy is also required by the Qur'an so that humans can admire God's work in the world. ${ }^{32}$

In line with the love of wisdom, Indonesia also has a principle of wisdom in every behavior, the feeling of humanity as love contains a consensus, namely Pancasila, in particular in the second principle that is Kemanusiaan yang adil dan beradab (just and civilized humanity) which contains humanitarian values, namely: 1) recognition of human dignity, 2) treatment that is fair to humans, 3) understanding human being civilized, creative and feeling, 4) the second principle inspired by the first precepts and animating the third, fourth and fifth precepts, should choose to think critically before behaving, acting, behaving and speaking. ${ }^{33}$ The noble values contained in Pancasila are indeed universal. From these characteristics, it appears how dynamic Pancasila is in keeping up with the changing times while remaining actual and noble.

Internalization in human value consisting in Pancasila, such as respecting opinions, caring for others, respecting others' rights and obligations through Ngaji Filsafat is indeed not explicitly like the Pancasila curriculum, even though the forum has also been reviewed. However, these values are implicit in every theme of the forum study because the study of MJS philosophy is not either theological or anthropocentric, but also theo-antropocentric. As the study of the philosophy of love, the study of philosophy about the teachings of ahimsa ${ }^{34}$, the study of philosophy about personality, the study of philosophy about the truth and so forth, have been held at MJS.

The change of thinking and behaving qualities in individual occurs. As the case in the practice of study forums that are open to all groups or between religions, they are held in places of worship of Muslims. There is no expulsion and rejection because they hold to the sincerity of their respective intentions. Changes to individuals are also recognized by the mosque takmir, the congregation or attendees. The forum is also attended by foreign people with whom the author met in person.

Therefore, authors argued that human value in Pancasila arranged by the founder of the nation, born from the womb of the Indonesian nation has the meaning that social and state attitudes as well as the basis for organizing governance are reflected in the noble values of the precepts. MJS forums which are small part of Indonesia, internalize human values of Pancasila through a philosophical forum implicitly through theories, ideas and figures so that they can take wisdom and the wise side as a paradigm to see how human nature should be, nature and become a weltanschauung (world view).

\section{Conclusion}

From the research conducted, the authors explain the findings that Jendral Sudirman Mosque is a mosque with three typical activities cores to prosper the mosque, such as spiritual, intellectual

32 Nurani Soyomukti, Pengantar Filsafat Umum: Dari Pendekatan Historis, Pemetaan Cabang-Cabang Filsafat, Pertarungan Pemikiran, Memahami Filsafat Cinta, Hingga Panduan Berpikir Kritis-Filosofis (Yogyakarta: Ar-Ruzz Media, 2011), https://perpusupb.files.wordpress.com/2018/07/pengantar-filsafat-umum.pdf.

${ }^{33}$ Asep Sulaiman, Pendidikan Pancasila Dan Kewarganegaraan (Bandung: CV Arfino Raya, 2015).

${ }^{34}$ Gandhi's teachings of Ahimsa or nonviolence are the most powerful force available to mankind. The first condition for ahimsa is total justice in every area of life I Gusti Made Widya Sena, "Humanisme Ajaran Ahimsa Dalam Membangun Toleransi (Perspektif Mahatma Gandhi)," PANGKAJA: JURNAL AGAMA HINDU, vol. 21 (Denpasar, July 4, 2018), http://ejournal.ihdn.ac.id/index.php/PJAH/article/view/540. 
and social culture. By showing that the mosque is not just a place of worship and prostration but also a place of study and ngaji. MJS is one of the mosques that still exists in the midst of modernization with a principle of nguri-uri budaya. As a mosque that is closely related to Javanese culture, it continues to preserve local wisdom while scheduling activities based on three core movements as an answer to the needs and problems of the people. MJS becomes one of the mosques that has a special characteristic. After fulfilling the mosque's main roles and functions that is for worship, Takmir of MJS able to seek for running events of the mosque by stepping forward to many scholarship activities that are usually only performed in the academic realm such as studying philosophy.

Through Ngaji Filsafat, MJS has changed a perspective that mosque is not only a place of worship but has the potential in the realm of scholarship. It can be utilized not only from academics and Muslims but by the wider community and all classes and between religions by promoting humanity awareness and returning everything to intention. It is very rare where philosophy is studied in a mosque and becomes a routine agenda. Furthermore, internalization of Pancasila's human values is implicitly found in each philosophical theme of the study delivered by the speakers by placing philosophy as a tool for finding and taking wisdom and the wisdom side of each theme or from philosophers. Therefore, an individual is aware of the nature of human and the universe.

\section{References}

A'yun, Qurrotul. "Transformasi Bentuk Fisik Pada Tipologi Fasade Masjid Jami' Malang." EMARA: Indonesian Journal of Architecture, 2016. https://doi.org/10.29080/eija.v1i2.9.

Adha, Muhammad Mona, and Erwin Susanto. "Kekuatan Nilai-Nilai Pancasila Dalam Membangun Kepribadian Masyarakat Indonesia." Al-Adabiya: Jurnal Kebudayaan Dan Keagamaan 15, no. 01 (July 4, 2020): 121-38. https://doi.org/10.37680/adabiya.v15i01.319.

Amin, Faizal, and Rifki Abror Ananda. "Kedatangan Dan Penyebaran Islam Di Asia Tenggara: Telaah Teoritik Tentang Proses Islamisasi Nusantara." Analisis: Jurnal Studi Keislaman, 2019. https://doi.org/10.24042/ajsk.v18i2.3069.

Amirudin, Teuku Supardi. Manajemen Masjid Dalam Pembangunan Masyarakat. Yogyakarta: UII Press, 2001.

Arikunto, Suharsimi. Metodologi Penelitian. Bumi Aksara, 2013.

Dwijayanto, Arik, \& Dawam Multazamy Rohmatulloh. "Ponorogo, the Little Java: Potret Kebudayaan Dan Keberagamaan Masyarakat Muslim Ponorogo Abad XX". Al-Adabiya: Jurnal Kebudayaan Dan Keagamaan 13, No. 01 (2018). https://doi.org/10.37680/adabiya.v13i01.2

Faiz, Fahruddin. Thinking Skill: Pengantar Berpikir Kritis. Yogyakarta: Suka Press, 2012. . Transkrip Ngaji Filsafat: Butir-Butir Kebijaksanaan Sufi Nusantara. Yogyakarta: Omah Ilmu, 2020.

Gazalba, Sidi. Masjid Pusat Ibadah Dan Kebudayaan Islam. Jakarta: Pustaka Antara, 1971.

Husein, Saddam. "Peran Masjid Dalam Pendidikan Islam Nonformal Untuk Pembinaan Umat (Studi Kasus Di Masjid Mardhatillah Gempol Ngadirejo Kartasura Sukoharjo)." Universitas Muhammadiyah Surakarta, 2015. 
Iwanebel, Fejrian Yazdajird. "Gerakan Keagamaan Dan Identitas Kultural Masjid Jendral Sudirman Yogyakarta." IBDA: Jurnal Kajian Islam Dan Budaya 17, no. 1 (2019). https://doi.org/10.24090/ibda.v17i1.2817

Kristianto, Paulus Eko. "Resensi: Paideia-Filsafat Pendidikan-Politik Platon." GEMA TEOLOGIKA: Jurnal Teologi Kontekstual dan Filsafat Keilahian 2, no. 2 (2017): 213-218. https://doi.org/10.21460/gema.2017.22.355.

Mahardhani, Ardhana Januar, and Hadi Cahyono. "Harmoni Masyarakat Tradisi Dalam Kerangka Multikuluralisme." ASKETIK: Jurnal Agama dan Perubahan Sosial 1, no. 1 (2017). https://doi.org/10.30762/ask.v1i1.408.

Mahardhani, Ardhana Januar. "Pemberdayaan Masyarakat Melalui Pendidikan Nonformal Berkarakter Cinta Tanah Air." Jurnal Pancasila Dan Kewarganegaraan, 2018. https://doi.org/10.24269/jpk.v3.n2.2018.pp56-63.

Moleong, Lexy J. "Metodologi Penelitian Kualitatif (Edisi Revisi)." PT. Remaja Rosda Karya, 2019. https://doi.org/10.1016/j.carbpol.2013.02.055.

Nurhadianto, Nurhadianto. "Internalisasi Nilai-Nilai Pancasila dalam Upaya Membentuk Pelajar Anti Narkoba." JURNAL PENDIDIKAN ILMU SOSIAL, 2016. https://doi.org/10.17509/jpis.v23i2.1618.

Rohmatulloh, Dawam Multazamy. "Local Muslim Heritage: Pelestarian Warisan Budaya Pesantren Di Tegalsari Ponorogo." Proceedings of Annual Conference for Muslim Scholars, 2018. http://proceedings.kopertais4.or.id/index.php/ancoms/article/view/125.

Semadi, Yoga Putra. "Filsafat Pancasila dalam Pendidikan di Indonesia Menuju Bangsa Berkarakter.” Jurnal Filsafat Indonesia, 2019. https://doi.org/10.23887/jfi.v2i2.21286.

Sena, I Gusti Made Widya. "Humanisme Ajaran Ahimsa Dalam Membangun Toleransi (Perspektif Mahatma Gandhi)." PANGKAJA: JURNAL AGAMA HINDU. Vol. 21. Denpasar, July 4, 2018. http://ejournal.ihdn.ac.id/index.php/PJAH/article/view/540.

Soyomukti, Nurani. Pengantar Filsafat Umum: Dari Pendekatan Historis, Pemetaan CabangCabang Filsafat, Pertarungan Pemikiran, Memahami Filsafat Cinta, Hingga Panduan Berpikir Kritis-Filosofis. Yogyakarta: Ar-Ruzz Media, 2011. https://perpusupb.files.wordpress.com/2018/07/pengantar-filsafat-umum.pdf.

Sulaiman, Asep. Pendidikan Pancasila Dan Kewarganegaraan. Bandung: CV Arfino Raya, 2015.

Sutarmadi, Ahmad. Manajemen Masjid Kontemporer. Jakarta: Balai Penerbit Fakultas Syariah dan Hukum UIN Syariah Hidayatullah, 2010.

Tanaka, Ahmad. "SISTEM AMONG, DALTON, DAN SHANTI NIKETAN Kajian Komparatif Historikal Sistem Pendidikan Indonesia, Amerika, Dan India Serta Implikasinya Bagi Kemajuan Pendidikan Di Indonesia Konteks Kekinian." Jurnal Teknologi Pendidikan Madrasah, 2018. http://journal.iaialmawar.ac.id/index.php/jtpm/article/view/83

Zein, Abdul B. Masjid-Masjid Bersejarah Di Indonesia. Jakarta: Gema Insani Press, 1999.

\section{Interviews}

Rahman, takmir of MJS and also participant of Ngaji Filsafat (Yogyakarta, January 9 and 12, 2020)

Wahid, takmir of MJS (Yogyakarta, January 9 and 10, 2020) 